BMJ Open Ophthalmology

\section{Coronavirus: good or bad news for ocular diseases?}

To cite: Navel V, Chiambaretta F, Dutheil F. Coronavirus: good or bad news for ocular diseases? BMJ Open Ophthalmology 2020;5:e000495. doi:10.1136/ bmjophth-2020-000495
Check for updates

(C) Author(s) (or their employer(s)) 2020. Re-use permitted under CC BY-NC. No commercial re-use. See rights and permissions. Published by BMJ.

${ }^{1}$ Ophthalmology, University Hospital of Clermont-Ferrand, Clermont-Ferrand, Auvergne Rhône Alpes, France

${ }^{2}$ Preventive and Occupational Medicine, University Hospital of Clermont-Ferrand, ClermontFerrand, Auvergne-Rhône-Alpes, France

Correspondence to Dr Valentin Navel; valentin. navel@hotmail.fr
To the editor: In urban area of industrial countries, the ocular surface is exposed daily to intense burden of particulate matter, ozone, carbon monoxide, nitrogen dioxide $\left(\mathrm{NO}_{2}\right)$ and sulfur dioxide produced by fossil fuel. Air pollution is a causative factor for various ocular surface complaints such as eye redness, irritation and blurring of vision, as well as various ocular diseases such as meibomian gland disease and dry eye disease, vernal keratoconjunctivitis, allergic conjunctivitis, retinal vein and artery occlusion, and glaucoma. $^{1-4}$ Putative pathophysiology of air pollutants is mediated by oxidative stress in ocular tissues exposed to atmospheric changes involving damage of cellular DNA, membrane lipids peroxidation, inactivation of receptor protein and enzymes, and finally cells apoptosis and autophagy mediated by autophagosome. ${ }^{35}$ Similarly, air pollutants promote neurotoxic and microvascular effects impacting on cardiovascular diseases as well as glaucoma and retinal vascular diseases. ${ }^{267}$ Since 8 December 2019, the world has been confronted by a viral pneumonia pandemic caused by the coronavirus named Severe Acute Respiratory Syndrome (SARS-CoV-2) or Coronavirus Disease 2019 (COVID-19). Initially described in Wuhan, Hubei, in the Peoples Republic of China, the movement of people and freight through tourism and commercial airline flights contributed to the spread of the global pandemic, causing millions of cases and tens of thousands of deaths. The local authorities responded quickly to promulgate quarantine status of epicentres such as towns, popular districts, production plants and other gathering places. Consequently, the reduction of human activities has impacted on greenhouse gas emissions from industry, tertiary services, mass transits or individual car circulation. NASA's Aura satellite described a marked reduction of nitrous oxide $\left(\mathrm{NO}_{2}\right)$ across China from 1-20 January 2020 (before the quarantine) to 10-25 February (during the quarantine) ${ }^{89}$ According to NASA scientists, the reduction in $\mathrm{NO}_{2}$ pollution was first apparent near Wuhan, but eventually spread across the country and around the world. A similar $\mathrm{NO}_{2}$ decrease across Europe, China and India were identified by Copernicus Sentinel-5P satellite, from the European Union Copernicus programme, during quarantine. ${ }^{10}{ }^{11}$ Globally, an $\mathrm{NO}_{2}$ decrease of $40 \%-50 \%$ over major cities across Asia, Europe or North America were measured following the decrease of global economy due to coronavirus epidemic (figure 1). ${ }^{8} 1011$ The impact of the global reduction of air pollution during SARS-CoV-2 pandemic could positively affect all the biodiversity of Earth, involving the slowdown of climatic change and the quality of freshwater. Therefore, the strong efforts of the international community to contain the COVID-19 epidemic may also have indirect health benefits by lowering the impact of air pollution on ocular diseases. Even if SARS-CoV-2 involves conjunctivitis and external ocular infections, ${ }^{12}$ there are not yet published data describing the effects of a reduction of air pollutants on the ocular surface during the quarantine period, and a putative decrease in some ocular complaints-individuals being at home and less exposed to pollens and atmospheric pollutants. However, all activities soliciting the near vision and accommodation were particularly increased during quarantine such as videogames, television, tele-working, reading and others activities in smartphone, putatively generating dry eye symptoms and visual fatigue. ${ }^{13}$ Also, it should be noted that a large number of doctors accidentally acquired coronavirus infection by contact with oropharyngeal fluids, but also tears and conjunctival secretions of patients ${ }^{14}$ particularly for patients with conjunctivitis. ${ }^{15}$ Furthermore, recent data highlighted that ocular symptoms could occur about 10-15 days after systemic contamination, with a low positivity rate of reverse transcription-PCR in tears and conjunctival samples (ie, conjunctival swab or/and scrapping). ${ }^{16}{ }^{17}$ SARS-CoV-2 patients without any ocular symptoms could 


\section{Before SARS-CoV-2 pandemic}

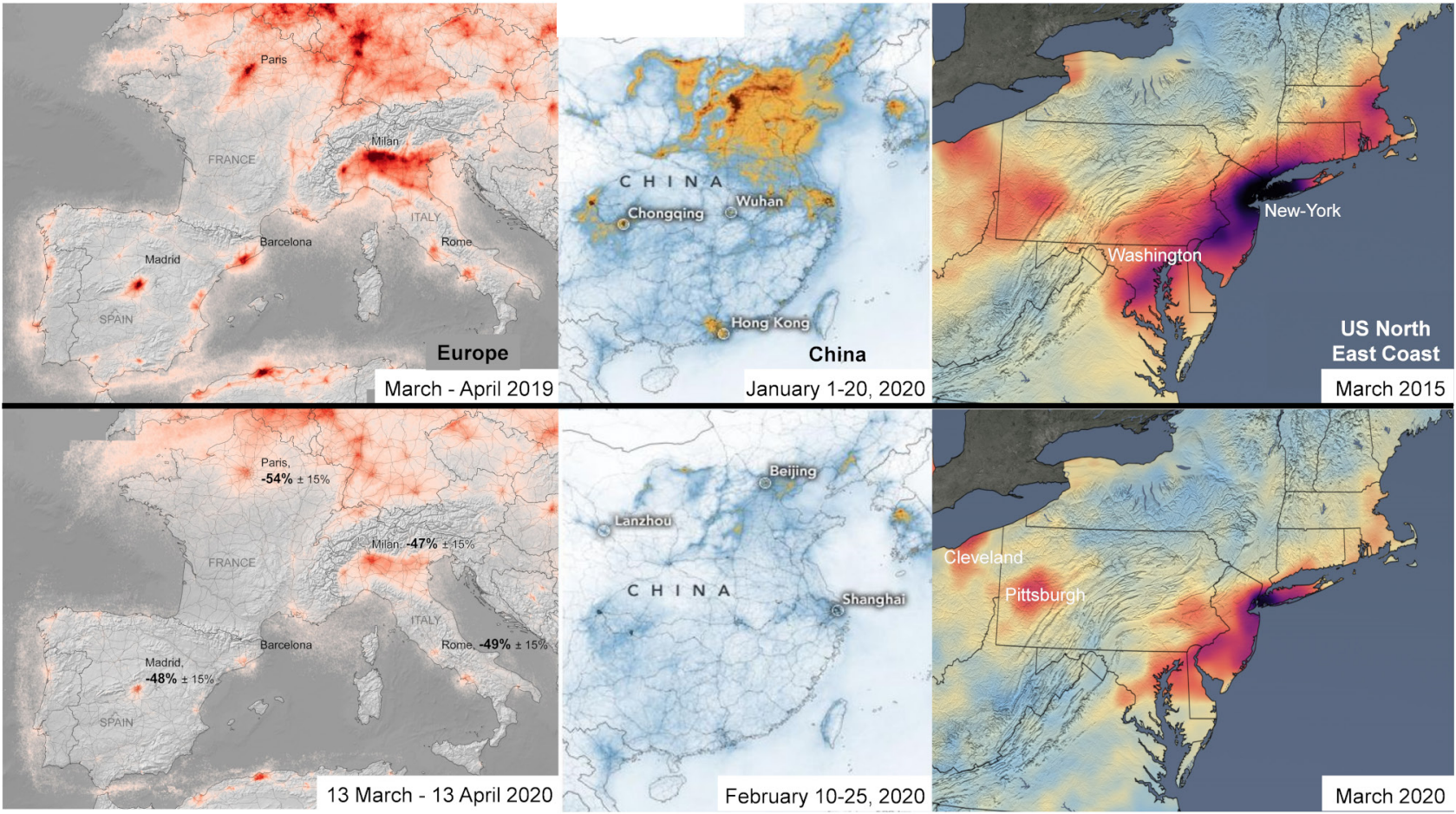

During SARS-CoV-2 containment

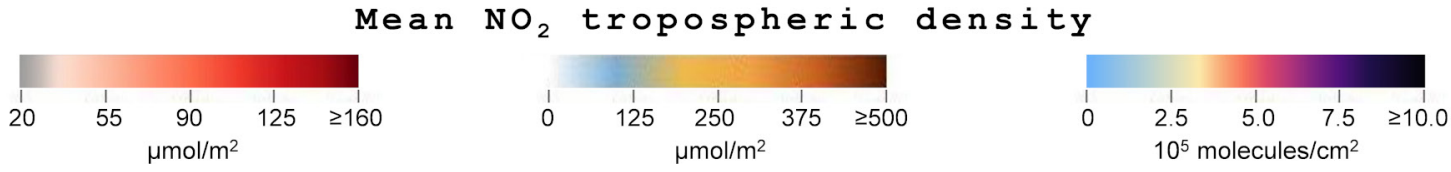

Figure 1 The decrease of global air pollution following the Severe Acute Respiratory Syndrome Coronavirus 2 (SARS-CoV-2) pandemic (satellite images from NASA and European Space Agency)..$^{8-11}$

also excreted SARS-CoV-2 in tears. ${ }^{18}$ Even if SARS-CoV-2 is an enveloped virus surviving a few hours or days on dry inert surfaces, the contaminated surfaces of ophthalmological consultation rooms are an established route of SARS-CoV-2 spreading. ${ }^{19}$ Thus, ophthalmologists are mainly concerned by an aerosol transmission, working in confined spaces at few centimetres from the faces of their patients, and a transmission by contact with tears or contaminated surfaces. Considering the contagiousness of the SARS-CoV-2, personal protective equipment is necessary in daily clinical practice: gloves and filtering face piece respirators (FFP2 or FFP3 masks) for the ophthalmologist and surgical facemasks for the patient. ${ }^{20} \mathrm{~A}$ plexiglass barrier (protective shield) between patient and ophthalmologist is as additional salient approach during close clinical and paraclinical examinations. ${ }^{21}$ Those preventive measures against SARS-CoV-2 will increase the duration of consultation, which will increase the waiting list for patients - that is already long and that may further delay medical treatment. ${ }^{22}$ In conclusion, even if individuals are less exposed to air pollutants and environmental allergens during quarantine weeks, SARS-CoV-2 seems to be a foe both for ophthalmologists—with a risk of infection through contact with eye secretions of patients-and for patients-with a delay in their medical management. The SARS-CoV-2 will probably upset ophthalmological practices during the forthcoming months or years.

Contributors VN and FD designed the study, planned and conducted the analysis of data, and wrote the manuscript. FC and FD conducted the literature search, the analyses of data, and reviewed the manuscript. All authors reviewed the final manuscript and approved the final version to be published.

Funding The authors have not declared a specific grant for this research from any funding agency in the public, commercial or not-for-profit sectors.

Map disclaimer The depiction of boundaries on this map does not imply the expression of any opinion whatsoever on the part of BMJ (or any member of its group) concerning the legal status of any country, territory, jurisdiction or area or of its authorities. This map is provided without any warranty of any kind, either express or implied.

Competing interests None declared.

Patient consent for publication Not required.

Provenance and peer review Not commissioned; internally peer reviewed.

Open access This is an open access article distributed in accordance with the Creative Commons Attribution Non Commercial (CC BY-NC 4.0) license, which permits others to distribute, remix, adapt, build upon this work non-commercially, and license their derivative works on different terms, provided the original work is properly cited, appropriate credit is given, any changes made indicated, and the use is non-commercial. See: http://creativecommons.org/licenses/by-nc/4.0/.

ORCID ID 
Valentin Navel http://orcid.org/0000-0001-6317-345X

\section{REFERENCES}

1 Jung SJ, Mehta JS, Tong L. Effects of environment pollution on the ocular surface. Ocul Surf 2018;16:198-205.

2 Cheng $\mathrm{H}-\mathrm{C}$, Pan $\mathrm{R}-\mathrm{H}$, Yeh $\mathrm{H}-\mathrm{J}$, et al. Ambient air pollution and the risk of central retinal artery occlusion. Ophthalmology 2016;123:2603-9.

3 Nwanaji-Enwerem JC, Wang W, Nwanaji-Enwerem O, et al. Association of long-term ambient black carbon exposure and oxidative stress allelic variants with intraocular pressure in older men. JAMA Ophthalmol 2019;137:129.

4 Chua SYL, Khawaja AP, Morgan J, et al. The relationship between ambient atmospheric fine particulate matter (PM2.5) and glaucoma in a large community cohort. Invest Ophthalmol Vis Sci 2019;60:4915.

5 Ma S, Yu Z, Feng S, et al. Corneal autophagy and ocular surface inflammation: a new perspective in dry eye. Exp Eye Res 2019;184:126-34.

6 Min K-B, Min J-Y. Association of ambient particulate matter exposure with the incidence of glaucoma in childhood. Am J Ophthalmol 2020;211:176-82.

7 Zhang H-W, Lin C-W, Kok VC, et al. Incidence of retinal vein occlusion with long-term exposure to ambient air pollution. PLOS One 2019;14:e0222895.

8 NASA. Airborne nitrogen dioxide plummets over China, 2020. Available: https://earthobservatory.nasa.gov/images/146362/ airborne-nitrogen-dioxide-plummets-over-china

9 NASA. Reductions in nitrogen dioxide associated with decreased fossil fuel use resulting from COVID-19 mitigation, 2020. Available: https://svs.gsfc.nasa.gov/4810

10 European Space Agency. Air pollution remains low as Europeans stay at home, 2020. Available: https://www.esa.int/Applications/ Observing_the_Earth/Copernicus/Sentinel-5P/Air_pollution_remains_ low_as_Europeans_stay_at_home
11 European Space Agency. Air pollution drops in India following lockdown., 2020. Available: https://www.esa.int/Applications/ Observing_the_Earth/Copernicus/Sentinel-5P/Air_pollution_drops_ in_India_following_lockdown

12 Navel V, Chiambaretta F, Dutheil F. Haemorrhagic conjunctivitis with pseudomembranous related to SARS-CoV-2. Am J Ophthalmol Case Rep 2020:100735.

13 Courtin R, Pereira B, Naughton G, et al. Prevalence of dry eye disease in visual display terminal workers: a systematic review and meta-analysis. BMJ Open 2016;6:e009675.

14 Lu C-W, Liu X-F, Jia Z-F. 2019-nCoV transmission through the ocular surface must not be ignored. Lancet 2020;395:e39.

15 Xia J, Tong J, Liu M, et al. Evaluation of coronavirus in tears and conjunctival secretions of patients with SARS-CoV-2 infection. J Med Virol 2020:jmv.25725.

16 Chen L, Liu M, Zhang Z, et al. Ocular manifestations of a hospitalised patient with confirmed 2019 novel coronavirus disease. Br J Ophthalmol 2020;104:748-51.

17 Napoli PE, Nioi M, d'Aloja E, et al. The Ocular Surface and the Coronavirus Disease 2019: Does a Dual 'Ocular Route' Exist? J Clin Med 2020;9:1269.

18 Xie H-T, Jiang S-Y, Xu K-K, et al. SARS-CoV-2 in the ocular surface of COVID-19 patients. Eye Vis 2020;7:23.

19 Otter JA, Donskey C, Yezli S, et al. Transmission of SARS and MERS coronaviruses and influenza virus in healthcare settings: the possible role of dry surface contamination. J Hosp Infect 2016;92:235-50.

20 Naveed H, Scantling-Birch Y, Lee H, et al. Controversies regarding mask usage in ophthalmic units in the United Kingdom during the COVID-19 pandemic. Eye 2020. doi:10.1038/s41433-020-0892-2. [Epub ahead of print: 23 Apr 2020].

21 Wong DHT, Mak ST, Yip NKF, et al. Protective shields for ophthalmic equipment to minimise droplet transmission of COVID-19. Graefes Arch Clin Exp Ophthalmol.

22 Quintana JM, Garcia S, Bilbao A, et al. Waiting time for cataract extraction: predictive factors and influence on outcomes. J Cataract Refract Surg 2011;37:19-26. 